\title{
The effect of scenario based teaching for critical care nurses and physicians on their knowledge of fluid creep
}

\author{
Ghada Shalaby Khalaf Mahran*1, Asmaa Ali Mahgoub ${ }^{1}$, Mostafa Samy Abass ${ }^{2}$ \\ ${ }^{1}$ Critical Care and Emergency Nursing, Faculty oof Nursing, Assiut University, Egypt \\ ${ }^{2}$ Anesthesia and Intensive Care, Faculty of Medicine, Assiut University, Egypt
}

Received: August 20, 2018

DOI: $10.5430 /$ jnep.v9n4p86
Accepted: December 6, $2018 \quad$ Online Published: December 28, 2018

URL: https://doi.org/10.5430/jnep.v9n4p86

\begin{abstract}
Introduction: Fluid resuscitation is a major component of the acute management of critically ill patients. The phenomenon of providing excessive fluid resuscitation volumes has been termed "fluid creep". Today, the science of nursing becomes more complex. Accurate fluid balance assessment and recording is important component of nursing care that assures patient's safety especially in critically ill patients. The aim of the work is to examine the effect of scenario based teaching for critical care nurses and physicians on their knowledge of fluid balance \& fluid creep.

Methods: The study design: pre \& posttest research design. Setting: This study was implemented in general, trauma, obstetric and burn intensive care units (ICUs) at Assiut university Hospital-Assiut-Egypt. Subjects: 35 critical care nurses and 29 intensive care physicians were drawn from the previously mentioned ICUs. Methodology: A pre \& posttest questionnaire of nurses' and physicians' knowledge, perception and satisfaction regarding fluid creep and fluid balance was adapted from the articles and was used in data collection before and after the application of scenario based teaching. This questionnaire was implemented on two phases (pre and after the teaching program). The data was collected from January 2018 to July 2018.

Results: There is a considerable improvement in participants' knowledge and perception concerning fluid balance and fluid creep after applying the scenario based teaching $(p$ value $<.001)$.

Conclusions: Nowadays, nurses and physicians need advanced level of knowledge to be able to deal with the physiological changes that occur in critically ill.
\end{abstract}

Key Words: Fluid balance, Monitoring, Fluid creep, Critical care nurses

\section{INTRODUCTION}

The management of intravenous fluids is important for physiological stability and tissue oxygen improvement. As patient's cardiac output increases consequently to fluid administration, the patient is effectively responses to fluid. On the other hand, once fluid has been adequately resuscitated, any additional fluid resuscitation may lead to fluid creep that result in an increase in intravascular pressure and vascular permeability which lead to fluid leakage, tissue edema ,hypoxic index ,increased intra-abdominal pressure and in- creased mortality. ${ }^{[1-4]}$

"Fluid creep" is a term recently applied to describe patients who receive fluid well in excess of the volumes predicted by traditional formulas for resuscitation such as the Parkland or Brooke formulas. ${ }^{[5]}$ Such over-resuscitation places patients at increased risk of highly lethal complications to include abdominal compartment syndrome. ${ }^{[6,7]}$

A growing body of evidence suggests that excess fluid overload may be harmful to critically ill patients. ${ }^{[8]}$ Recent stud-

*Correspondence: Ghada Shalaby Khalaf Mahran; Email: ghada.mahran@ nursing.aun.edu.eg; Address: Critical Care and Emergency Nursing, Faculty oof Nursing, Assiut University, Egypt. 
ies have reported that excess fluid has been associated with adverse outcomes in patients with acute lung or kidney injury. Based on the findings of the various studies that were conducted on the intensive care patients suggesting that excess fluid lead to negative outcomes, fluid balance assessment and management become crucial in those patients. ${ }^{[9]}$ Moreover, in acutely ill patients positive mean daily fluid balance was indicated as a considerable predictor of death. ${ }^{[10,11]}$ Relatively little attention has been paid to the consequences of excess fluid such as respiratory failure increased cardiac demand and peripheral edema. Although there is no uniform definition of excess fluid or fluid creep and well-designed randomized clinical trials there appears to be a need to avoid excessive fluid resuscitation in a subset of patients. ${ }^{[12]}$

The process of reviewing intravenous fluids and diuretics prescription by junior doctors is very important. Accurate knowledge of fluid status is crucial in any decision related to patient's care. ${ }^{[13]}$ The Physical assessment and examination of the patients and the measurement of biomarkers may be useful but anomalies only begin to emerge once the fluid state becomes severely abnormal. Inaccurate monitoring of input/output may result in delayed identification of fluid state distortions then ineffective decision-making. ${ }^{14-16]}$

The accuracy of fluid balance control is an element of nursing intervention that ensures patients' safety, especially patients requiring intensive care. Correct recording of fluids is a cornerstone in the management of fluid balance. Any defect in recording or missing numbers or observations can harm the patients. ${ }^{[17-20]}$ The nurses in the critical care settings respond to the patient's needs with the evidenced nursing practice. The critical care nurse is the person who responsible for accurate fluid balance recording. Therefore, the nurse should recognize and respond to irregularities and fluid balance disorders. Furthermore, closely observe the charts, the hemodynamic stability. ${ }^{[18,21]}$

The previous studies have shown that the nursing teaching of nurses working in intensive care areas by the educational method is very inefficient to enhance their knowledge and practice. Therefore, it is important to use the suitable manner in teaching the nurses in these areas. This teaching manner should enhance and develop critical thinking and clinical reasoning skills for nurses and enable them to response to any demand or change in patients care or in the system of health care. Scenario-based teaching is one of the teaching system that depend on the philosophy to teach the learners the skills of critical thinking. ${ }^{[22]}$

Scenario-based teaching is considered as an approach that represents the strategy of implementing a task in a real situation. The use of various skills by the learners is the basic of designing the teaching contents of the real scenarios. The results of using such a method are the achieving and fulfillment of the goals. In addition, learners become more familiar with these methods of knowledge acquisition and gathering of information. ${ }^{[23,24]}$

Different schools and teaching institutes have created numerous chances and opportunities to develop practical nursing by running scenario-based teaching programs. This scenario empowers the study groups to adjust their time and resources and focus their knowledge in patients care. This scenario also has a positive impact on the mentality and clinical practice of the nurses. ${ }^{[23]}$ Given the critical importance of nurse care practices in the critical care unit, taking into account the fact that the nurses in this unit face critical conditions, complicated situations and sensitive patients whose lives are at risk, performance enhancement and knowledge mastery of care is essential to all.

\section{Methodology}

\subsection{Research design}

This pre $\&$ posttest research design of the critical care nurses \& physicians was conducted from January 2018 to July 2018.

\subsection{The research hypothesis}

- A significant difference between pre \& posttest nurses' knowledge versus physicians regarding the physiology of fluid balance.

- A significant difference between pre \& posttest nurses' knowledge versus physicians regarding fluid creep.

\subsection{Objective}

To examine the effect of a scenario based teaching for critical care nurses and physicians on their knowledge of fluid balance \& fluid creep.

\subsection{The study site}

The study site included four different intensive care units (Trauma ICU, general ICU, obstetric ICU and burn ICU) at Assuit University Hospitals.

\subsection{The focus group}

- Based on a bilateral testing model, we estimated 64 nursing and physicians' subjects would be required to detect a 25\% improvement in knowledge of fluid creep and the appropriate fluid balance monitoring with a power of $80 \%$ and a final $p$ value of .05 .

- The participants of this study were a convenience sample of 35 nurses and 29 doctors who were included in patients' care in the intensive care units and meet the eligibility criteria. 


\subsection{Inclusion criteria}

- Nurses \& physicians who were involved in patients care especially patients who receive fluid therapy (burned patients, shocked patients) in direct and continuous manner.

- Nurses \& physician with more than one year experience.

\subsection{Exclusion criteria}

- Nurse management facilitator \& physician who not responsible for direct care for critically ill patients.

- Student nurses and physicians.

- Nurses or physicians not present during the study duration.

\subsection{Ethical consideration}

A research proposal was presented to the Ethical Committee at the Faculty of Nursing Assiut University. Each ICU coordinator was informed about the study and provided their oral support and written consent to the study. Participants were given information about the study to help them make an informed decision about participation.

\subsection{Data collection tools}

The data collection tools included the author-made questionnaire composed of 6 parts: The first part included questions about the demographic characters of the nurses, the second part included questions regarding fluid balance, the third part included questions about fluid creep, the fourth part included questions about nurses and physician opinion regarding fluid balance monitoring, and the fifth part included questions about nurses and physician satisfaction regarding current practice of fluid balance monitoring

\subsection{Data collection phases}

The study comprised three distinct phases including:

A) Preparatory phase that included: (i) development of a paper and pencil questionnaire about fluid balance $\&$ fluid creep (two months); (ii) pilot testing of the questionnaire (one month); (iii) implementation of the pretest questionnaire (one month).

B) Intervention phase that included the implementation of scenario based teaching about fluid balance monitoring and fluid creep (two months).

C) Evaluation of the effect of the scenario (one month).

\subsubsection{Preparatory phase}

\section{(1) Development of the questionnaire}

The questionnaire was a tool for collecting self-reporting data where participants present their perception and knowledge about fluid balance \& fluid creep. The questionnaire was developed from international articles and publications describing best practices relating to all relevant aspects of fluid balance monitoring. ${ }^{[16,25]}$ It was easy to administer, not time consuming, enabling access to larger samples.

\section{(2) Parts of the questionnaire}

- Questions related to demographic data (open questions)

- Questions related to nurses \& physician knowledge about fluid physiology and fluid creep which are as important as it provides an insight into the current knowledge (multiple choice questions with only one possible answer per question). The questions were discussed with critical care staff experienced in critical care nursing, medical and education (applied twice: pre \& post the teaching program).

- Questions regarding nurses and physician perception regarding fluid balance monitoring (Likert scale design which include four opinion: strongly agree, agree, disagree, strongly disagree) (applied twice: pre \& post the teaching program).

- Questions about nurses and physician satisfaction regarding current practice of fluid balance monitoring (Likert scale design which includes four satisfaction categories: strongly satisfied, satisfied, dissatisfied, and strongly dissatisfied). (Applied once: pre the teaching program).

- The questionnaire was designed in English because all nurses and physician are bachelor and master degree (their study was in English when they were studying in their faculty) and hospital documents are in English. Moreover, the participants were able to communicate in the English.

\section{(3) Piloting the questionnaire}

The pilot questionnaire was tested once the approval of the ethical committee was received. The pilot study was conducted on 3 nurses and 3 physicians. The reason for selecting these nurses $\&$ physicians was to test the tool with a set that reflects the expected appearance of the target population and identify any confusing and irrelevant questions. Any comments from nurses $\&$ doctors about the questionnaire were provided.

\section{(4) The final questionnaire}

The last edition of the questionnaire contained thirty five questions. The questionnaire included: (five questions) related to personal data (Age, unit, level of experience, educational level, and previous training about fluid creep), (thirteen questions) of nurses \& physician knowledge about fluid creep, (twelve questions) about nurses and physician opinion regarding fluid balance monitoring, and (five questions) 
about nurses and physician satisfaction regarding fluid balance monitoring.

\section{(5) The scoring system of the questionnaire}

- The second and third parts were evaluated as each correct answer was scored one degree and zero for wrong answer.

- The total score of knowledge was scored as $75 \%$ or more of correct answer is considered good level of knowledge, $60 \%$ to less than $75 \%$ is considered faire level, but less than $60 \%$ was considered poor level.

\section{(6) Validity \& reliability}

The researcher gave the questionnaire to 6 experts in critical care nursing $\&$ medicine to review and examine the quality of the questionnaire. The reliability and validity of the instruments gives an attribute of the study and reduce the bias level. Included test retest reliability and internal validity was measured by correlation coefficient (Cronbach alpha was $0.87)$.

\section{(7) Implementing the questionnaire}

The questionnaire was copied twice according to the number of the participants (each participants has two hard copies).

The implementation process of the questionnaire consisted of two stages:

Stage I: Upon completion of the questionnaire, the researcher distributed the first copy of the question to the participants for implementation at the beginning of the study before the implementation of the scenario teaching sessions (pretest) to form a baseline data.

Stage II: The questionnaire was implemented by the participants again (the second copy of the questionnaire) after the teaching sessions (posttest) as an evaluation of the effect of the scenario compared to the baseline data.

The questionnaires were distributed by the research in the selected units on nurses and doctors at the time of their rest to assure that patient care is not affected. The researcher met each participant individually to clarify any question. After completion of the questionnaire the researcher collect it.

\subsubsection{Intervention phase}

- Before running the scenario-based learning program, the subjects were asked to evaluate a real life 6 burned patients which were selected by the researcher from the burn ICU during their acute phase of resuscitation.

- As the subjects completed their assessment and evaluation of the patients, they were asked to answer the questions in the second part of the questionnaire.

- Moreover, each subject was specifically asked to determine whether the assessed patient was in fluid creep or not, define fluid creep, determine signs of fluid creep, causes of this phenomenon, complication that may occur, and how to manage (answer the questions in the third part of the questionnaire).

- Furthermore, each subject was asked to complete the fourth parts of the questionnaire.

- Moreover, each subject was specifically asked to evaluate the current fluid balance monitoring especially the fluid input and output chart by using the fifth part of the questionnaire.

- The researcher then collected the completed copies of the questionnaire from all the subjects to assess their response as a pretest base line data.

\section{The scenario based teaching program}

Based on the available resources and nursing instructions, the researcher began developing and preparing scientific scenarios for fluid balance monitoring and fluid creep with slide presentation. The sessions were done at each unit by the researcher. The contents of program were designed on the basis of the available publications on fluid balance monitoring and fluid creep. ${ }^{[3-7]}$ The scenarios were then submitted to six experts from critical care nursing and intensive care medicine) to examine the program tools thoroughly. After receiving the comments, the final scenarios were utilized in the final intervention. The program continued for two months and composed of four main parts were included in fourteen sessions (45 minutes for each session).

Part I: The physiology of fluid balance (4 sessions) included:

- Phases of fluid resuscitation.

- Types of fluids.

- The differences between resuscitation fluid, replacement fluid and maintenance fluid.

- Physiology of fluid balance.

- Consequences of fluid imbalance on critically ill patients' outcome.

Part II: The fluid creep (2 sessions) included:

- Definition of fluid creep.

- Risk factors of fluid creep.

- Complication of fluid creep.

- Management of fluid creep.

Part III: The fluid balance monitoring (4 sessions) included:

- The importance of fluid balance monitoring.

- The practice of accurate fluid balance monitoring.

Part IV: The Patient scenario (4 sessions):

- Four scenarios were applied in intensive care settings for different patients and associated questions were 
developed and adopted by a focus group comprising two experienced staff (one physician and an anesthesiologist), two experienced critical care nurses ( $>10$ years) and one critical care research nurse. Consistent with the theory of textual compatibility, each patient scenario contains insufficient knowledge about the clinical presentation of fluid creep, and the integration of fluid balance control to better reflect the reality of clinical practice.

- These different scenarios were consisting of the teaching components, not as a part of the assessment, to improve the level of information and ability of nurses and physicians to monitor fluid balance, to detect fluid creep and to foster information-collection and clinical reasoning. The study groups were asked to reflect on whether the patient in the scenario had fluid creep, and which of the described clinical features supported this premise. The didactic presentation consisted of a 20 -slide presentation lasting 30-45 minutes. The scenarios presented at the conference hall in ICU to study groups at least four nurses and doctors during the same shift as the bedside evaluations. The same presentation was used at each site.

- The program was performed after the pretest questionnaire collection to avoid the program effect on the response of nurses and physician. The researcher displayed posters around nurses \& doctors' areas on the units.

\subsubsection{The evaluation phase}

After the end of scenario-based training program, the knowledge of nurses and physician regarding fluid balance mon- itoring and fluid creep was measured again using the same questionnaire.

\subsection{Data analysis}

SPSS for Windows version 16.00 (SPSS Inc., Chicago, IL, USA) was used for statistical analysis. Descriptive statistics are presented by numbers (n), percentages (\%) and as mean (standard deviation). Normality of data distribution was evaluated with the Kolmogorov-Smirnov test. A $p$-value $<.05$ was accepted as the indicator of statistical significance.

\section{RESUlts}

The majority of the physicians (19 out of $29 ; 65.5 \%$ ) were in the age group 25 to 30 years, versus a number of 11 nurses $(31.4 \%)$ in the same age group. Only 8 participating nurses $(22.9 \%)$ were available in the age group less than 25 years old. More than half of the participating nurses (51.4\%) and physicians $(65.5 \%)$ have less than 4 years' experience. Highly percent of nurses $(68.6 \%)$ and physicians $(65.5 \%)$ were bachelor degree. The highest percent of nurses were working in the general and trauma intensive care units (65.5\%). In the other hand, only $8.6 \%$ of nurses were working in burn unit versus the number of physicians was equal in the three units' trauma, general and obstetric intensive care units with a percent of $24.1 \%$. All participants didn't receive any previous training or audit related to fluid creep (see Table 1).

Regarding to the nurses' and physicians' knowledge regarding the physiology of fluid therapy, there is a significant improvement in the knowledge after the application of the scenario ( $p$ value <.001) (see Table 2$)$.

Table 1. The frequency distribution of critical care nurses' \& physicians socio-demographic criteria

\begin{tabular}{llll}
\hline Items & & Nurses (N = 35) & Physician (N = 29) \\
\hline & $20-<25$ years & $8(22.9 \%)$ & 0 \\
Age & $25-<30$ & $11(31.4 \%)$ & $19(65.5 \%)$ \\
& $30-<35$ & $6(17.1 \%)$ & $10(34.5 \%)$ \\
& $35-40$ & $4(11.4 \%)$ & 0 \\
Year of experience & $40-45$ & $6(17.1 \%)$ & $19(65.5 \%)$ \\
& $1-<4$ years & $18(51.4 \%)$ & $10(34.5 \%)$ \\
Education & $4-<8$ & $11(31.4 \%)$ & $0(0)$ \\
& $8-10$ & $6(17.1 \%)$ & $19(65.5 \%)$ \\
& Bachelor & $24(68.6 \%)$ & $10(34.5 \%)$ \\
Units & Master & $11(31.4 \%)$ & $7(27.6 \%)$ \\
& Burn & $3(8.6 \%)$ & $7(24.1 \%)$ \\
& Trauma & $13(37.1 \%)$ & $7(24.1 \%)$ \\
Previous training/audit about fluid creep & $13(37.1 \%)$ & $7(24.1 \%)$ \\
& General & $6(17.1 \%)$ & 0 \\
& Ybstetric & 0 & $29(100 \%)$ \\
\hline
\end{tabular}


Table 2. The frequency distribution of critical care nurses' \& physicians' knowledge regarding fluid balance in ICUs

\begin{tabular}{|c|c|c|c|c|c|c|c|c|c|}
\hline \multirow{2}{*}{\multicolumn{2}{|c|}{ Questions regarding fluid balance }} & \multicolumn{2}{|l|}{ Pre-test } & \multicolumn{2}{|l|}{ Post-test } & \multirow[b]{2}{*}{$p 1$} & \multirow[b]{2}{*}{$p 2$} & \multirow[b]{2}{*}{ p3 } & \multirow[b]{2}{*}{$p 4$} \\
\hline & & \multirow{2}{*}{$\begin{array}{l}\begin{array}{l}\text { Nurses } \\
\mathbf{n}=\mathbf{3 5}\end{array} \\
26(74.28 \%)\end{array}$} & \multirow{2}{*}{ 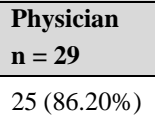 } & \multirow{2}{*}{$\begin{array}{l}\begin{array}{l}\text { Nurses } \\
\mathbf{n}=\mathbf{3 5}\end{array} \\
33(94.3 \%)\end{array}$} & \multirow{2}{*}{ 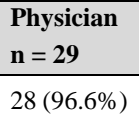 } & & & & \\
\hline .... is given as therapy to achieve & Resuscitation fluid & & & & & \multirow{4}{*}{.412} & \multirow{4}{*}{$.04 *$} & \multirow{4}{*}{.33} & \multirow{4}{*}{1} \\
\hline (increased urine output, & Replacement fluid & $5(14.28 \%)$ & $3(10.34 \%)$ & $2(5.7 \%)$ & $1(3.4 \%)$ & & & & \\
\hline $\begin{array}{l}\text { improved mentation) or } \\
\text { hemodynamic improvement in a }\end{array}$ & Maintenance fluid & $4(11.42 \%)$ & $1(3.44 \%)$ & 0 & 0 & & & & \\
\hline $\begin{array}{l}\text { inflammatory response or shock } \\
\text { state. }\end{array}$ & Don’t know & 0 & 0 & 0 & 0 & & & & \\
\hline \multirow{4}{*}{$\begin{array}{l}\text { What are the two systems in the } \\
\text { human body mainly monitored } \\
\text { to assess the fluid balance? }\end{array}$} & Circulatory \& renal & $28(80 \%)$ & $29(100 \%)$ & 33 (94.3\%) & $29(100 \%)$ & \multirow{4}{*}{$.039 *$} & \multirow{4}{*}{0.13} & \multirow{4}{*}{1} & \multirow{4}{*}{.49} \\
\hline & $\begin{array}{l}\text { Respiratory \& } \\
\text { circulatory }\end{array}$ & $4(11.42 \%)$ & 0 & $2(5.7 \%)$ & 0 & & & & \\
\hline & Renal \& gastrointestinal & $3(8.57 \%)$ & 0 & 0 & 0 & & & & \\
\hline & Hepatic \& lymphatic & 0 & 0 & 0 & 0 & & & & \\
\hline \multirow{4}{*}{$\begin{array}{l}\ldots . . \text { is a potential marker for } \\
\text { fluid therapy: }\end{array}$} & $\begin{array}{l}\text { Brain natriuretic } \\
\text { peptide }\end{array}$ & $21(60 \%)$ & $15(72.41 \%)$ & $33(94.3 \%)$ & $26(89.7 \%)$ & \multirow{4}{*}{.471} & \multirow{4}{*}{$.005^{*}$} & \multirow{4}{*}{.19} & \multirow{4}{*}{.65} \\
\hline & Ammonia & $6(17.1 \%)$ & 7 (13.79\%) & $2(5.7 \%)$ & $3(10.3 \%)$ & & & & \\
\hline & Troponin & $5(14.3 \%)$ & $2(3.44 \%)$ & 0 & 0 & & & & \\
\hline & Thiamine & $3(8.6 \%)$ & $5(10.34 \%)$ & 0 & 0 & & & & \\
\hline \multirow{4}{*}{$\begin{array}{l}\text { Phase of fluids resuscitation, in } \\
\text { which patients are given rapid } \\
\text { fluid bolus therapy as the } \\
\text { mainstay of treatment to rapidly } \\
\text { reverse volume-responsive } \\
\text { shock states and improve organ } \\
\text { perfusion }\end{array}$} & Rescue (or Salvage) & $6(17.1 \%)$ & 15 (51.7\%) & 31 (88.6\%) & 26 (89.7\%) & \multirow{4}{*}{$.02 *$} & \multirow{4}{*}{$.000 *$} & \multirow{4}{*}{$.009 *$} & \\
\hline & Optimization & 12 (34.3\%) & 7 (24.1\%) & $4(11.4 \%)$ & $3(10.3 \%)$ & & & & \\
\hline & Stabilization & $8(22.9 \%)$ & $5(17.2 \%)$ & 0 & 0 & & & & 1 \\
\hline & De-escalation (ROS-D) & $9(25.7 \%)$ & $2(6.9 \%)$ & 0 & 0 & & & & \\
\hline & Rescue (or Salvage) & $9(25.7 \%)$ & $4(13.8 \%)$ & $3(8.6 \%)$ & 0 & & & & \\
\hline The final phase of fluids & Optimization & $9(25.7 \%)$ & $3(10.3 \%)$ & $4(11.4 \%)$ & $1(3.4 \%)$ & $001 *$ & $000 *$ & $02 *$ & 11 \\
\hline resuscitation & Stabilization & $11(31.4 \%)$ & $3(10.3 \%)$ & 0 & 0 & & & & \\
\hline & De-escalation (ROS-D) & $6(17.1 \%)$ & 19 (65.5\%) & $28(80 \%)$ & $28(96.6 \%)$ & & & & \\
\hline & Protein & $20(57.1 \%)$ & $29(100 \%)$ & 33 (94.3\%) & $29(100 \%)$ & & & & \\
\hline The plasma oncotic pressure & Carbohydrate & $6(17.1 \%)$ & 0 & $2(5.7 \%)$ & 0 & $001 *$ & $003 *$ & 1 & 49 \\
\hline Levels drop during resuscitation. & Fat & $3(8.6 \%)$ & 0 & 0 & 0 & .001 & .005 & 1 & .49 \\
\hline & Vitamins & $6(17.1 \%)$ & 0 & 0 & 0 & & & & \\
\hline & Forces fluids in & $9(25.7 \%)$ & 0 & $3(8.6 \%)$ & 0 & & & & \\
\hline & Forces fluids out & $14(40 \%)$ & $29(100 \%)$ & 32 (91.4\%) & $29(100 \%)$ & & & & \\
\hline Capillary hydrostatic pressure & $\begin{array}{l}\text { Has no role in fluid } \\
\text { balance }\end{array}$ & $7(20 \%)$ & 0 & 0 & 0 & $.000^{*}$ & $.000^{*}$ & 1 & .24 \\
\hline & Do not know & $5(14.3 \%)$ & 0 & 0 & 0 & & & & \\
\hline
\end{tabular}

${ }^{*} p<.05 ; p 1=$ pre-test; $p$ value for nurses $\&$ physician; $p 2$ = pre \&post-test for nurses; $p 3=$ pre $\&$ post-test for physician; $p 4=$ post-test for nurses $\&$ physician.

Regarding to the nurses' and physicians' knowledge regard- after the application of the scenario based teaching. All ing the fluid creep, there is a significant improvement in the participants agreed with the statements "Inaccurate fluid balknowledge after the application of the scenario ( $p$ value $<$ ance calculation can be a risk for the critically ill patient", .001) (see Table 3).

Regarding to the nurses' and physicians' mean knowledge score regarding the physiology of fluid therapy and fluid creep, there is a significant improvement in the knowledge after the application of the scenario $(p$ value $<.001)$ (see Table 4).

The perception of nurses and physicians has been improved the concept that positive fluid balance harm patients as negative balance, Fluid balance assessment is important to guide nursing care in critically ill patients, audit undertaken weekly and scores shared with staff, focused face-to-face training for all ICU nursing staff followed by individual assessments, the final 24-hour fluid balance is correctly calculated all the time, each unit team should have a specific target to meet the "fluid balance challenge", develop new audit tool to monitor 
fluid recording, which will allow to assess the effectiveness of the strategy, covering fluid balance as part of the wellestablished daily multidisciplinary ICU round, to ensure that fluid balance is considered by all clinical staff, including the anaesthetist, resident medical officer and nursing staff, highly visible information boards on fluid management in relevant clinical settings and redesigning the fluid prescribing and monitoring charts so that monitoring expectations are clear to all relevant staff"' (see Table 5).

Table 3. The frequency distribution of critical care nurses' \& physicians' knowledge regarding fluid creep in ICUs

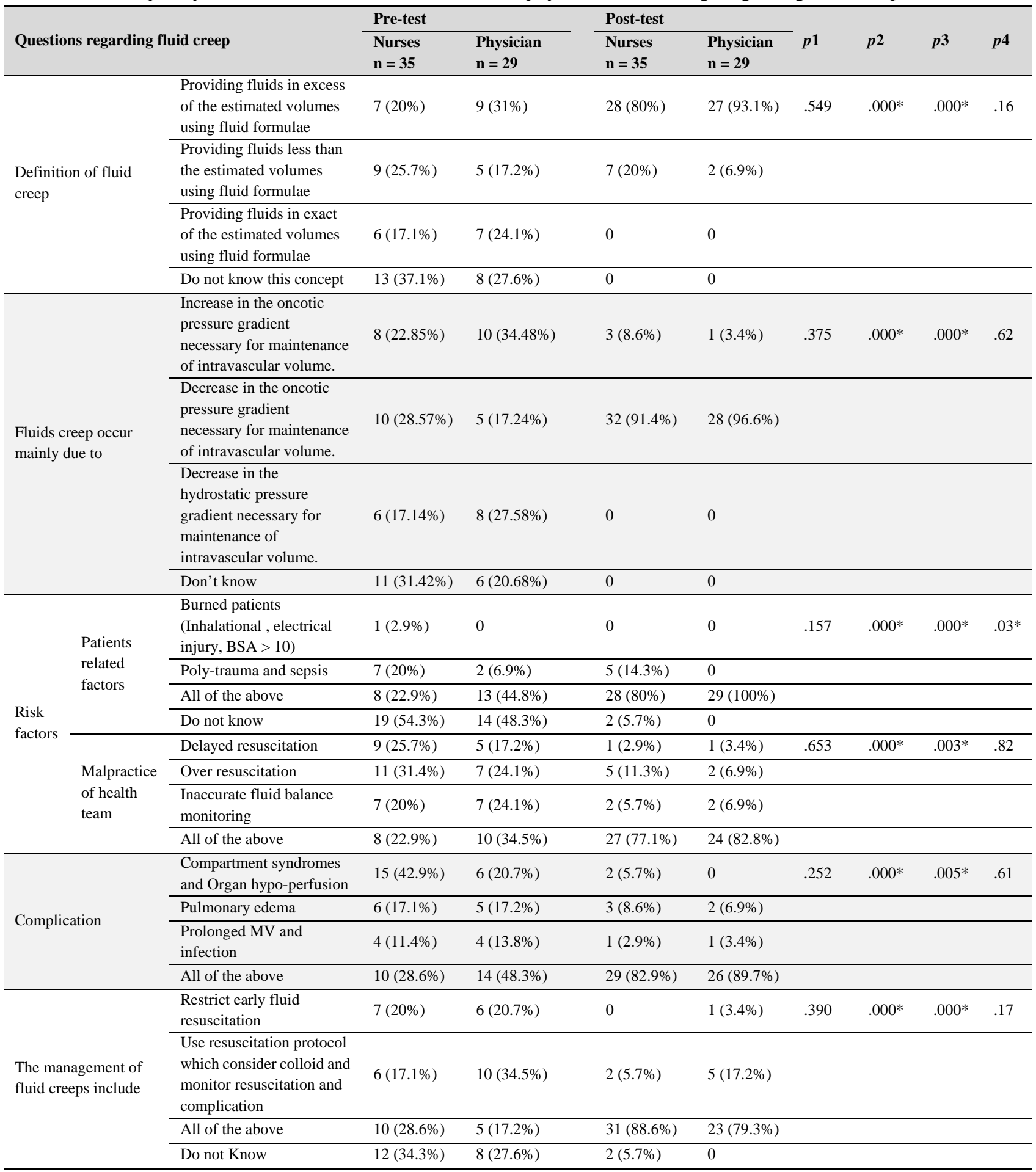

${ }^{*} p<.05 ; p 1$ = pre-test $\mathrm{p}$ value for nurses \&physician; $p 2$ = pre \&post-test for nurses; $p 3$ = pre \&post-test for physician; $p 4$ = post-test for nurses \& physician. 
Table 4. Critical care nurses' \& physicians' perception regarding fluid balance monitoring in ICUs

\begin{tabular}{|c|c|c|c|c|c|c|c|c|c|c|c|c|c|c|c|c|c|}
\hline \multirow{3}{*}{$\begin{array}{l}\text { Perception } \\
\text { regarding fluid } \\
\text { balance } \\
\text { monitoring }\end{array}$} & \multicolumn{8}{|l|}{ Pretest } & \multicolumn{8}{|c|}{ Posttest } & \multirow{3}{*}{$p$} \\
\hline & \multicolumn{4}{|c|}{ Nurses $(\mathrm{N}=35)$} & \multicolumn{4}{|c|}{ Physician $(\mathrm{N}=29)$} & \multicolumn{4}{|c|}{ Nurses $(\mathrm{N}=35)$} & \multicolumn{4}{|c|}{ Physician $(\mathrm{N}=29)$} & \\
\hline & $\begin{array}{l}\text { 1* } \\
\text { n (\%) }\end{array}$ & $\begin{array}{l}2^{*} \\
\text { n (\%) }\end{array}$ & $\begin{array}{l}\text { 3* } \\
\text { n (\%) }\end{array}$ & $\begin{array}{l}4^{*} \\
\text { n (\%) }\end{array}$ & $\begin{array}{l}\text { 1* } \\
\text { n (\%) }\end{array}$ & $\begin{array}{l}2^{*} \\
\text { n (\%) } \\
\end{array}$ & $\begin{array}{l}* \\
\text { n (\%) }\end{array}$ & $\begin{array}{l}4^{*} \\
\text { n (\%) }\end{array}$ & $\begin{array}{l}\text { 1* } \\
\text { n (\%) }\end{array}$ & $\begin{array}{l}2^{*} \\
\text { n }(\%)\end{array}$ & $\begin{array}{l}* \\
\text { n (\%) }\end{array}$ & $\begin{array}{l}4^{*} \\
\text { n (\%) }\end{array}$ & $\begin{array}{l}\text { 1* } \\
\text { n (\%) }\end{array}$ & $\begin{array}{l}2^{*} \\
\text { n (\%) }\end{array}$ & $\begin{array}{l}\text { 3* } \\
\text { n (\%) }\end{array}$ & $\begin{array}{l}4^{*} \\
\text { n (\%) }\end{array}$ & \\
\hline $\begin{array}{l}\text { Inaccurate fluid } \\
\text { balance } \\
\text { calculation can } \\
\text { be a risk for the } \\
\text { critically ill } \\
\text { patient }\end{array}$ & $\begin{array}{l}18 \\
(51.42)\end{array}$ & $\begin{array}{l}17 \\
(48.57)\end{array}$ & 0 & 0 & $\begin{array}{l}23 \\
(79.31)\end{array}$ & $\begin{array}{l}6 \\
(20.68)\end{array}$ & 0 & 0 & $\begin{array}{l}35 \\
(100)\end{array}$ & 0 & 0 & 0 & $\begin{array}{l}29 \\
(100)\end{array}$ & 0 & 0 & 0 & .000 \\
\hline $\begin{array}{l}\text { Positive fluid } \\
\text { balance harm } \\
\text { patients as } \\
\text { negative balance }\end{array}$ & $\begin{array}{l}8 \\
(22.85)\end{array}$ & $\begin{array}{l}20 \\
(57.14)\end{array}$ & $\begin{array}{l}5 \\
(14.28)\end{array}$ & $\begin{array}{l}2 \\
(5.71)\end{array}$ & $\begin{array}{l}6 \\
(20.68)\end{array}$ & $\begin{array}{l}18 \\
(62.0)\end{array}$ & $\begin{array}{l}5 \\
(17.24)\end{array}$ & 0 & $\begin{array}{l}35 \\
(100)\end{array}$ & 0 & 0 & 0 & $\begin{array}{l}29 \\
(100)\end{array}$ & 0 & 0 & 0 & .000 \\
\hline $\begin{array}{l}\text { Doctors are } \\
\text { persons who } \\
\text { responsible for a } \\
\text { correct fluid } \\
\text { balance } \\
\text { calculation }\end{array}$ & $\begin{array}{l}28 \\
(80)\end{array}$ & $\begin{array}{l}7 \\
(20)\end{array}$ & 0 & 0 & $\begin{array}{l}8 \\
(27.58)\end{array}$ & $\begin{array}{l}14 \\
(48.27)\end{array}$ & $\begin{array}{l}2 \\
(6.89)\end{array}$ & $\begin{array}{l}5 \\
(17.24)\end{array}$ & $\begin{array}{l}20 \\
(57.1)\end{array}$ & $\begin{array}{l}5 \\
(14.3)\end{array}$ & $\begin{array}{l}10 \\
(28.6)\end{array}$ & 0 & $\begin{array}{l}16 \\
(55.2)\end{array}$ & $\begin{array}{l}4 \\
(13.8)\end{array}$ & $\begin{array}{l}9 \\
(31)\end{array}$ & 0 & .000 \\
\hline $\begin{array}{l}\text { Fluid balance } \\
\text { assessment is } \\
\text { important to } \\
\text { guide nursing } \\
\text { care in critically } \\
\text { ill patients }\end{array}$ & $\begin{array}{l}19 \\
(54.28)\end{array}$ & $\begin{array}{l}16 \\
(45.71)\end{array}$ & 0 & 0 & $\begin{array}{l}29 \\
(100)\end{array}$ & 0 & 0 & 0 & $\begin{array}{l}35 \\
(100)\end{array}$ & 0 & 0 & 0 & $\begin{array}{l}29 \\
(100)\end{array}$ & 0 & 0 & 0 & .000 \\
\hline $\begin{array}{l}\text { Audit } \\
\text { undertaken } \\
\text { weekly and } \\
\text { scores shared } \\
\text { with staff }\end{array}$ & $\begin{array}{l}30 \\
(85.71)\end{array}$ & $\begin{array}{l}3 \\
(8.57)\end{array}$ & $\begin{array}{l}2 \\
(5.71)\end{array}$ & 0 & $\begin{array}{l}29 \\
(100)\end{array}$ & 0 & 0 & 0 & $\begin{array}{l}31 \\
(88.6)\end{array}$ & $\begin{array}{l}3 \\
(8.6)\end{array}$ & $\begin{array}{l}1 \\
(2.9)\end{array}$ & 0 & $\begin{array}{l}29 \\
(100)\end{array}$ & 0 & 0 & 0 & .19 \\
\hline $\begin{array}{l}\text { Focused } \\
\text { face-to-face } \\
\text { training for all } \\
\text { ICU nursing } \\
\text { staff followed by } \\
\text { individual } \\
\text { assessments }\end{array}$ & $\begin{array}{l}22 \\
(62.9)\end{array}$ & $\begin{array}{l}11 \\
(31.4)\end{array}$ & $\begin{array}{l}2 \\
(5.7)\end{array}$ & 0 & $\begin{array}{l}29 \\
(100)\end{array}$ & 0 & 0 & 0 & $\begin{array}{l}35 \\
(100)\end{array}$ & 0 & 0 & 0 & $\begin{array}{l}29 \\
(100)\end{array}$ & 0 & 0 & 0 & .000 \\
\hline $\begin{array}{l}\text { Highly visible } \\
\text { information } \\
\text { boards on fluid } \\
\text { management in } \\
\text { relevant clinical } \\
\text { settings }\end{array}$ & $\begin{array}{l}35 \\
(100)\end{array}$ & 0 & 0 & 0 & $\begin{array}{l}29 \\
(100)\end{array}$ & 0 & 0 & 0 & $\begin{array}{l}35 \\
(100)\end{array}$ & 0 & 0 & 0 & $\begin{array}{l}29 \\
(100)\end{array}$ & 0 & 0 & 0 & 1 \\
\hline $\begin{array}{l}\text { Redesigning the } \\
\text { fluid prescribing } \\
\text { and monitoring } \\
\text { charts so that } \\
\text { monitoring } \\
\text { expectations are } \\
\text { clear to all } \\
\text { relevant staff }\end{array}$ & $\begin{array}{l}35 \\
(100)\end{array}$ & 0 & 0 & 0 & $\begin{array}{l}29 \\
(100)\end{array}$ & 0 & 0 & 0 & $\begin{array}{l}35 \\
(100)\end{array}$ & 0 & 0 & 0 & $\begin{array}{l}29 \\
(100)\end{array}$ & 0 & 0 & 0 & 1 \\
\hline $\begin{array}{l}\text { Covering fluid } \\
\text { balance as part } \\
\text { of the well- } \\
\text { established daily } \\
\text { multidisciplinary } \\
\text { ICU round, to } \\
\text { ensure that fluid } \\
\text { balance is } \\
\text { considered by all } \\
\text { clinical staff, } \\
\text { including the } \\
\text { anaesthetist, } \\
\text { resident medical } \\
\text { officer and } \\
\text { nursing staff }\end{array}$ & $\begin{array}{l}35 \\
(100)\end{array}$ & 0 & 0 & 0 & $\begin{array}{l}29 \\
(100)\end{array}$ & 0 & 0 & 0 & $\begin{array}{l}35 \\
(100)\end{array}$ & 0 & 0 & 0 & $\begin{array}{l}29 \\
(100)\end{array}$ & 0 & 0 & 0 & 1 \\
\hline $\begin{array}{l}\text { New audit tool to } \\
\text { monitor fluid } \\
\text { recording, which } \\
\text { will allow to } \\
\text { assess the } \\
\text { effectiveness of } \\
\text { our strategy }\end{array}$ & $\begin{array}{l}35 \\
(100)\end{array}$ & 0 & 0 & 0 & $\begin{array}{l}29 \\
(100)\end{array}$ & 0 & 0 & 0 & $\begin{array}{l}35 \\
(100)\end{array}$ & 0 & 0 & 0 & $\begin{array}{l}29 \\
(100)\end{array}$ & 0 & 0 & 0 & 1 \\
\hline $\begin{array}{l}\text { The final } \\
\text { 24-hour fluid } \\
\text { balance is } \\
\text { correctly } \\
\text { calculated all the } \\
\text { time }\end{array}$ & $\begin{array}{l}27 \\
(77.1)\end{array}$ & $\begin{array}{l}8 \\
(22.9)\end{array}$ & 0 & 0 & $\begin{array}{l}29 \\
(100)\end{array}$ & 0 & 0 & 0 & $\begin{array}{l}27 \\
(77.1)\end{array}$ & $\begin{array}{l}8 \\
(22.9)\end{array}$ & 0 & 0 & $\begin{array}{l}29 \\
(100)\end{array}$ & 0 & 0 & 0 & .000 \\
\hline $\begin{array}{l}\text { Each unit team } \\
\text { should has a } \\
\text { specific target to } \\
\text { meet the 'fluid } \\
\text { balance } \\
\text { challenge' }\end{array}$ & $\begin{array}{l}35 \\
(100)\end{array}$ & 0 & 0 & 0 & $\begin{array}{l}29 \\
(100)\end{array}$ & 0 & 0 & 0 & $\begin{array}{l}35 \\
(100)\end{array}$ & 0 & 0 & 0 & $\begin{array}{l}29 \\
(100)\end{array}$ & 0 & 0 & 0 & 1 \\
\hline
\end{tabular}


Table 5. Critical care nurses' \& physicians' satisfaction level regarding current fluid balance monitoring in ICUs

\begin{tabular}{|c|c|c|c|c|c|c|c|c|}
\hline \multirow{2}{*}{$\begin{array}{l}\text { Satisfaction level of current } \\
\text { fluid balance monitoring }\end{array}$} & \multicolumn{4}{|c|}{ Nurses $(n=35)$} & \multicolumn{4}{|c|}{ Physician $(n=29)$} \\
\hline & 1* & $2 *$ & $3 *$ & 4* & $1 *$ & $2 *$ & $3 *$ & $4 *$ \\
\hline $\begin{array}{l}\text { Satisfied with the design of the } \\
\text { fluid chart sheet }\end{array}$ & 0 & $\begin{array}{l}11 \\
(31.42 \%)\end{array}$ & $\begin{array}{l}9 \\
(25.71 \%)\end{array}$ & $\begin{array}{l}15 \\
(42.85 \%)\end{array}$ & 0 & $\begin{array}{l}8 \\
(27.58 \%)\end{array}$ & $\begin{array}{l}6 \\
(20.68 \%)\end{array}$ & $\begin{array}{l}15 \\
(51.72 \%)\end{array}$ \\
\hline $\begin{array}{l}\text { Satisfied with supervision of } \\
\text { all the fluid balance activities }\end{array}$ & 0 & 0 & $\begin{array}{l}25 \\
(71.42 \%)\end{array}$ & $\begin{array}{l}10 \\
(28.57 \%)\end{array}$ & 0 & 0 & 0 & $\begin{array}{l}29 \\
(100 \%)\end{array}$ \\
\hline $\begin{array}{l}\text { The adequacy of the time for } \\
\text { fluid balance monitoring }\end{array}$ & 0 & 0 & $\begin{array}{l}5 \\
(14.28 \%)\end{array}$ & $\begin{array}{l}30 \\
(85.71 \%)\end{array}$ & 0 & 0 & 0 & $\begin{array}{l}29 \\
(100 \%)\end{array}$ \\
\hline $\begin{array}{l}\text { The accuracy of fluid balance } \\
\text { monitoring }\end{array}$ & 0 & $\begin{array}{l}2 \\
(5.71 \%)\end{array}$ & $\begin{array}{l}8 \\
(22.85 \%)\end{array}$ & $\begin{array}{l}25 \\
(71.42 \%)\end{array}$ & 0 & 0 & 0 & $\begin{array}{l}29 \\
(100 \%)\end{array}$ \\
\hline Average chart completion rate & 0 & $\begin{array}{l}5 \\
(14.28 \%)\end{array}$ & 0 & $\begin{array}{l}30 \\
(85.71 \%)\end{array}$ & 0 & 0 & 0 & $\begin{array}{l}29 \\
(100 \%)\end{array}$ \\
\hline
\end{tabular}

Note. $1^{*=}$ strongly agree, $2^{*}=$ agree, $3^{*}=$ disagree, $4^{*}=$ strongly disagree

All participants were not satisfied with the design of the fluid chart sheet. In the other hand $(31.42 \%)$ of nurses versus $(27.58 \%)$ of physicians were satisfied. All participants were dissatisfied with the supervision of all the fluid balance activities, the adequacy of the time for fluid balance monitoring, accuracy of fluid balance monitoring and Average chart completion rate except $(5.71 \%, 14.28 \%)$ of nurses were satisfied with accuracy of fluid balance monitoring and average chart completion respectively.

\section{Discussion}

Intensive care nurses have developing information that continues in progress with practice, so it is difficult to define information in nursing. In the last decades, nurses were the bedside hands of doctors. Recently, nursing became an independent profession, although nursing is still striving to achieve acknowledgement. The sources of nursing knowledge are various, such as physiology and psychology. Practice is considered the important source of nursing knowledge. ${ }^{[16]}$

It is obvious from the findings of the current study that nurses' and physicians' knowledge about fluid balance improved after the application of the scenario. These results were in line with the study of Vijayan (2011) ${ }^{[26]}$ which assessed the nurses' performance regarding fluid and electrolyte administration in patients underwent open heart surgery and admitted in ICU. The study showed that half of nurses had sufficient knowledge; more than two thirds of nurses have moderately adequate level of knowledge whilst the remaining number of nurses had insufficient knowledge. There also another support from a study of nurses' perception about fluid therapy was conducted by Kanakalakshmi (2014). ${ }^{[27]}$ The researchers found that more than tens of nurses had sufficient knowledge, just over three thirds have moderately sufficient knowledge and just over two thirds have insufficient knowledge level. In this study, the implementation of the scenario improved the level of knowledge from adequate to highly adequate.

Others published studied have examined the effectiveness of curriculum-based teaching in different groups ${ }^{[24,28,29]}$ which recently has been considered as a teaching stimulant with real patients and used commonly in the clinical fields. ${ }^{[30]}$ The findings of the study of Michelson highlighted that the use of this strategy of teaching in the units of infection increases the students' understanding and facilitates the dealing with complex issues. ${ }^{[31]}$ Nestel et al also believe that scenariobased teaching combined with simulation may improve the techniques and methods of nursing, especially the techniques of communication. ${ }^{[32]}$ This teaching method is based on the principles of adults' teaching and situational teaching theory and provides us with a learner-based opportunity for the complicated issues.

Looking more closely to the findings related to nurses' and physicians' knowledge about fluid creep, it can be seen that the level of knowledge was poor and low in the pretest which improved dramatically after the application of the scenario. This may be contributed as the participants didn't receive any previous educative sections about fluid creep. Another attribute is may be due to their over involvement in patients care, they ignore the importance of the educative sections about fluid balance. They consider the fluid balance is very simple concept is routinely monitored in patients. It can be considered that the main source of knowledge in the ICUs is clinical practice not theories. These findings were in contrast with Diacon (2012) ${ }^{[21]}$ who reported that critical care nurses are equipped with theoretical and practical knowledge about fluid balance monitoring.

These results were supported with those of Doulin et al. ${ }^{[33]}$ According to the statistical analysis in our study achieved in their research, scenario-based learning has improved the 
information of nurses and helped them to correctly diagnose and assess delirium in the hospital's critical care unit. In another research conducted by Majdi Nasef, utilizing scenariobased training improved information and improved the performance of nurses during their professional challenges at Al Azhrar Hospital in Egypt. Based on these findings, Majdi Nasef et al. stressed the urgent need for remedial education centers to change strategies for in-service training for nurses and to benefit from modern and creative training methods such as scenario-based learning. ${ }^{[34]}$ In another research conducted by Dehkordi et al. the use of problem-focused methods improved the presentation and performance of nursing students in internal surgery courses. ${ }^{[35]}$ The results of this research are consistent with the results of Staun et al. and Heso et al. ${ }^{[23,36]}$ According to these studies, the use of problem-centered and scenario-based educational methods has improved the performance of participants in the intervention group.

As regard to the participants' perception of fluid balance monitoring, all participants agreed that with the statement "Inaccurate fluid balance calculation can be a risk for the critically ill patient and positive fluid balance can harm the patients". These findings were supported by many people as Diacon (2012) ${ }^{[21]}$ and Asfour (2016) ${ }^{[10]}$ besides numerous studies indicated an increase in mortality rate associated with positive fluid balance. ${ }^{[18,37-39]}$ This reflects the importance of accurate fluid balance monitoring toward patients' safety.

All nurses agreed on the opinion "Doctors are persons who responsible for a correct fluid balance calculation versus only just over one third of physicians who are disagreed on this statement". This was in contrast with Diacon $(2014)^{[16]}$ who reported that more than four thirds of the participants stated that the registered nurse was the only person who responsible for accurate fluid balance assessment. Moreover, in the study of Asfour (2016), ${ }^{[10]}$ nurses did not agree on that too many people fill in one patient's fluid balance chart and mentioned that the nurse is the only responsible for a correct fluid balance calculation.

All physicians and nurses agree on the opinions "Fluid balance assessment is important in guiding nursing care in critically ill patients". This reflects that nurses and physicians are concerned by patients care in a holistic approach. These findings were in line with Diacon (2012) ${ }^{[21]}$ and Asfour $(2016)^{[10]}$ who stated that more than four thirds of the participants agree that the fluid balance plays an important role in their nursing care. According to Culleiton (2011), ${ }^{[40]}$ nurses should be able to recognize and react to fluid balance irregularities.

Most of physicians and nurses agree on the opinions "Audit undertaken weekly and scores shared with staff with focused face-to-face training for all ICU nursing staff followed by individual assessments". This reflects the high tendency of nurses and physicians to improve their knowledge regarding fluid balance monitoring. All participants agreed that each unit team should have a specific target to meet the 'fluid balance challenge, develop new audit tool to monitor fluid recording. These data were in line with Diacon (2012) ${ }^{[21]}$ who recommended the continuous assessment and updating of the fluid balance chart and each intensive care unit should has its individual chart.

The majority of physicians and nurses in this study agree on the opinions "The final 24-hour fluid balance is correctly calculated all the time, covering fluid balance as part of the well-established daily multidisciplinary ICU round, to ensure that fluid balance is considered by all clinical staff, including the anaesthetist, resident medical officer and nursing staff, highly visible information boards on fluid management in relevant clinical settings, redesigning the fluid prescribing and monitoring charts so that monitoring expectations are clear to all relevant staff". These results were in line with Bennett (2010) ${ }^{[41]}$ who recommended the regular assessment and updating of the charts of fluid balance and should be designed for each unit. In addition, Asfour (2016) ${ }^{[10]}$ reported that in Vincent (2015) ${ }^{[42]}$ project nurses suggested that the results would improve if they had more direction and orientation from the medical team about monitoring and more education on fluid balance. Moreover, Diacon (2014) ${ }^{[16]}$ suggested various solutions to improve fluid balance monitoring in his study which included: staff training on infusion pumps and basic calculation, clear uniform charts, clear physicians' prescriptions, bedside calculator, documentation audits, information signs at the bedside. In addition, Herbert (2016) ${ }^{[39]}$ recommended that the guidelines of the prescribed fluid in the intensive care setting should be introduced.

Most participants were dissatisfied with the fluid chart design. Some nurses comment that it should contain a signature for the responsible nurse and doctor observation each shift. Moreover, should contain a space for documenting any drug that interferes with fluid balance as diuretics. This was in contrary with the results of Diacon (2012) ${ }^{[21]}$ and Asfour $(2016)^{[10]}$ who mentioned that the majority of nurses agreed that the design of their units chart of fluid balance was well.

Nowadays, cumulative inputs and outputs charts is questioned in the publications. ${ }^{[41]}$ Perren $(2011)^{[37]}$ suggested that cumulative fluid balance charts should be checked on regular basis especially in acutely ill. In this study, all participants were dissatisfied with the supervision of all the fluid balance activities, the adequacy of the time for fluid balance 
monitoring, accuracy of fluid balance monitoring. This defect may be due to various factors as lack of nursing staff, knowledge deficiency and workload as each nurse has two patients to care for them, or maybe there was no adequate space in the chart design for accurate documentation. Another cause for inaccurate fluid balance monitoring may be a result of overlapping or missed recording of continuous intravenous infusions and/or diuretics.

In this regard, Walker $(2012)^{[43]}$ conducted a study on intravenous fluids and checked 53 charts of the prescribed intravenous fluids before administration and 48 after administration, the findings of the study showed that further assessment and documentation of fluid balance status by medical staff came as a result of careful finishing of the charts by the staff of nursing. As regard to this concern, Vincent $(2015)^{[42]}$ conducted an audit of fluid balance control for more than one hundred patients and showed that the number of the fully completed charts were less than half of fluid balance charts.

\section{Strength and limitations}

The strength of our study is that it is the first to broadly survey multi-intensive care units within an institution to better understand cross-disciplinary care concerns around fluid creep. Moreover, the time constraints and workload of the participants who work in a critical care environment was an important limitation issue.

\section{Conclusion}

Monitoring the patient's fluid balance is of great importance in understanding and managing a patient's clinical status. Therefore, accurate fluid balance monitoring plays an essential role in patient care management. Scenario-based learning helps nurses gain the experience of working in the critical care unit, develop their skills and acquire the necessary skills without any fear or concern about causing harm to the patient.

\section{CONFLicts OF InTEREST Disclosure}

The authors declare that there is no conflict of interest.

\section{REFERENCES}

[1] Cordemans C, et al. Fluid management in critically ill patients: the role of extravascular lung water, abdominal hypertension, capillary leak, and fluid balance. Annals of Intensive Care. 2012; 2(1): S1. PMid:22873410 https://doi .org/10.1186/2110-5820-2 -S1-S1

[2] Koonrangsesomboon W, Khwannimit B. Impact of positive fluid balance on mortality and length of stay in septic shock patients. Indian Jurnal of Critical Care medicine. 2015; 19(12): 708. PMid:26813080 https : //doi.org/10.4103/0972-5229.171356

[3] Lansdorp B. Predicting fluid responsiveness in ICU patients: from physiology to bedside. 2014.

[4] Malbrain ML, et al. Fluid overload, de-resuscitation, and outcomes in critically ill or injured patients: a systematic review with suggestions for clinical practice. Anaesthesiology Intensive Therapy. 2014; 46(5): 361-380. PMid:25432556 https://doi .org/10.5603/AI T. 2014.0060

[5] Atiyeh B, et al. Acute burn resuscitation and fluid creep: it is time for colloid rehabilitation. Annals of Burns and Fire Disasters. 2012; 25(2): 59. PMid:23233822

[6] Cancio L, et al. STEMMING THE TIDE OF "FLUID CREEP" IDENTIFICATION OF BURN PATIENTS AT RISK OF OVERRESUSCITATION. Critical Care Medicine. 2013; 41(12): A51. https://doi.org/10.1097/01.ccm.0000439372.97744.dc

[7] Sirvent JM, et al. Fluid balance in sepsis and septic shock as a determining factor of mortality. The American Journal of Emergency Medicine. 2015; 33(2): 186-189. PMid:25483379 https: //doi.org/10.1016/j.ajem.2014.11.016

[8] Chou YH, Chen YF, Lin SL. More is not better: fluid therapy in critically ill patients with acute kidney injury. Journal of the Formosan Medical Association. 2013; 112(3): 112-114. PMid:23473522 https://doi.org/10.1016/j.jfma.2012.05.007

[9] You JW, et al. Association between weight change and clinical outcomes in critically ill patients. Journal of Critical Care. 2013;
28(6): 923-927. PMid:24075294 https://doi.org/10.1016/j . jcrc. 2013.07.055

[10] Asfour HI. Fluid balance monitoring accuracy in intensive care units. IOSR J Nur Heal Sci. 2016; 5(4VI): 53-62. https : //doi .org/10 .9790/1959-0504015362

[11] Ralib AM, et al. The Impact of Fluid Balances in the First 48 Hours on Mortality in the Critically Ill Patients. International Medical Journal Malaysia. 2016; 15(1): 13-18.

[12] Lee JW. Fluid and electrolyte disturbances in critically ill patients. Electrolytes \& Blood Pressure. 2010; 8(2): 72-81. PMid:21468200 https://doi.org/10.5049/EBP. 2010.8.2.72

[13] Kalantari K, et al. Assessment of intravascular volume status and volume responsiveness in critically ill patients. Kidney International. 2013; 83(6): 1017-1028. PMid:23302716 https ://doi .org/10.1 038/ki.2012.424

[14] Excellence NIFC. Intravenous fluid therapy in adults in hospital. NICE Clinical Guideline. 2013.

[15] Leach RM. et al. Nutrition and fluid balance must be taken seriously. BMJ. 2013; 346: f801. PMid:23396386 https://doi .org/10.1 $136 / \mathrm{bmj} . \mathrm{f} 801$

[16] Diacon A, Bell J. Investigating the recording and accuracy of fluid balance monitoring in critically ill patients. Southern African Journal of Critical Care (Online). 2014; 30(2): 55-57. https ://doi .org/ 10.7196/SAJCC. 193

[17] Gonzalez F, Vincent F. The fluid balance in the critically ill patients: what are we talking about? 2011.

[18] Shepherd A. Measuring and managing fluid balance. Nursing Times. 2011; 107(28): 12-16. PMid:21941718

[19] Welch K. Fluid balance. Learning Disability Practice (through 2013). 2010; 13(6): 33.

[20] Commission CQ. Dignity and nutrition for older people: review of compliance. CQC, London: 2011.

[21] Diacon A. Fluid balance monitoring in critically ill patients. 2012. 
[22] MOHAMMADI GR, Ebrahimian A, MAHMOUDI H. Evaluating the knowledge of intensive care unit nursing staffs. 2009.

[23] Hsu LL, Huang YH, Hsieh SI. The effects of scenario-based communication training on nurses' communication competence and self-efficacy and myocardial infarction knowledge. Patient Education and Counseling. 2014; 95(3): 356-364. PMid:24718019 https://doi.org/10.1016/j.pec.2014.03.010

[24] Nagle BM, et al. Incorporating scenario-based simulation into a hospital nursing education program. The Journal of Continuing Education in Nursing. 2009; 40(1): 18-25. PMid:19226995 https: //doi.org/10.3928/00220124-20090101-02

[25] Rewa O, Bagshaw SM. Principles of fluid management. Critical Care Clinics. 2015; 31(4): 785-801. PMid:26410145 https://doi.or $\mathrm{g} / 10.1016 / \mathrm{j}$.ccc.2015.06.012

[26] Vijayan A. A study to assess the knowledge and practices staff nurses regarding fluid and electrolyte amdinistration in post operative cardiac surgical patients admitted in cardiac surgical ICU and cardiac surgical ward, SCTIMST, Trivandrum. 2011.

[27] Kanakalakshmi R. Knowledge and practice regarding fluid and electrolyte replacement therapy for patient with burns among working nurses. NARAYANA NURSING JOURNAL. 2014; 3(4): 34-36.

[28] Lynch MD. Developing a scenario-based training program: Giving officers a tactical advantage. FBI L. Enforcement Bull. 2005; 74: 1.

[29] Rahmani A, Moradi Y, Mohammadi A. Effectiveness of scenariobased education on the performance of the nurses in the critical cardiac care unit for patients with acute coronary syndrome. International Journal of Medical Research \& Health Sciences. 2016; 5(8): 218-224

[30] Jones MC, Johnston DW. Is the introduction of a student-centred, problem-based curriculum associated with improvements in student nurse well-being and performance? An observational study of effect. International Journal of Nursing Studies. 2006; 43(8): 941-952. PMid:16376348 https://doi.org/10.1016/j.ijnurstu. 200 5.10 .013

[31] Mikkelsen J, Reime MH, Harris AK. Nursing students' learning of managing cross-infections-Scenario-based simulation training versus study groups. Nurse Education Today. 2008; 28(6): 664-671. PMid:18164104 https://doi.org/10.1016/j.nedt.2007.11 .003

[32] Nestel D, Kneebone R, Kidd J. Teaching and learning about skills in minor surgery. Journal of Clinical Nursing. 2003; 12(2): 291-296.
PMid:12603563 https://doi.org/10.1046/j.1365-2702.20 $03.00694 . \mathrm{x}$

[33] Devlin JW, et al. Combined didactic and scenario-based education improves the ability of intensive care unit staff to recognize delirium at the bedside. Critical Care. 2008; 12(1): R19. PMid:18291021 https://doi.org/10.1186/cc6793

[34] Nasef MM, et al. Active learning versus lecture-based approaches in occupational training programs of intensive care nursing staff at Al-Ahrar Hospital, Zagazig City, Egypt. Gaziantep Medical Journal. 2014; 20(2): 147-159. https://doi .org/10.5455/GMJ-30-150 254

[35] Dehkordi AH, Heydarnejad MS. The impact of problem-based learning and lecturing on the behavior and attitudes of Iranian nursing students. Dan Med Bull. 2008; 55(4): 224-6. PMid:19232163

[36] Staun M, Bergström B, Wadensten B. Evaluation of a PBL strategy in clinical supervision of nursing students: Patient-centred training in student-dedicated treatment rooms. Nurse Education Today. 2010; 30(7): 631-637. PMid:20061069 https ://doi .org/10.1016/j . nedt. 2009.12.013

[37] Perren A, et al. Fluid balance in critically ill patients. Should we really rely on it? Minerva Anestesiologica. 2011; 77(8): 802-811. PMid:21730928

[38] Boyd JH, et al. Fluid resuscitation in septic shock: a positive fluid balance and elevated central venous pressure are associated with increased mortality. Critical Care Medicine. 2011; 39(2): 259-265. PMid:20975548 https://doi.org/10.1097/CCM.0b013e3181 feeb15

[39] Herbert L, Elsayed I, McDougall M. Fluid and Electrolyte Balance in the Intensive Care Unit-Trickle or Flood? 2016.

[40] Nursing 2018. Critical Care. 2011; 6(3): 27-32. https://doi .or g/10.1097/01.CCN.0000396958.02554.f9

[41] Bennett C. At A Glance'Fluid Balance Bar Chart. London: NHS institute for innovation and improvement. 2010.

[42] Vincent M, et al. Fluid balance monitoring: a Quality Improvement project. BMJ Qual Improv Report. 2015.

[43] Walker G, et al. Intravenous fluid use in the acutely unwell adult medical inpatient: improving practice through a clinical audit process. The Journal of the Royal College of Physicians of Edinburgh. 2012; 42(3): 211-215. PMid:22953313 https : //doi .org/10.4997/JR CPE. 2012.304 